\title{
蛙
}

SEP 201996 GNGINEERNG DATA TRANGMITTAL

$\operatorname{lot} 1$

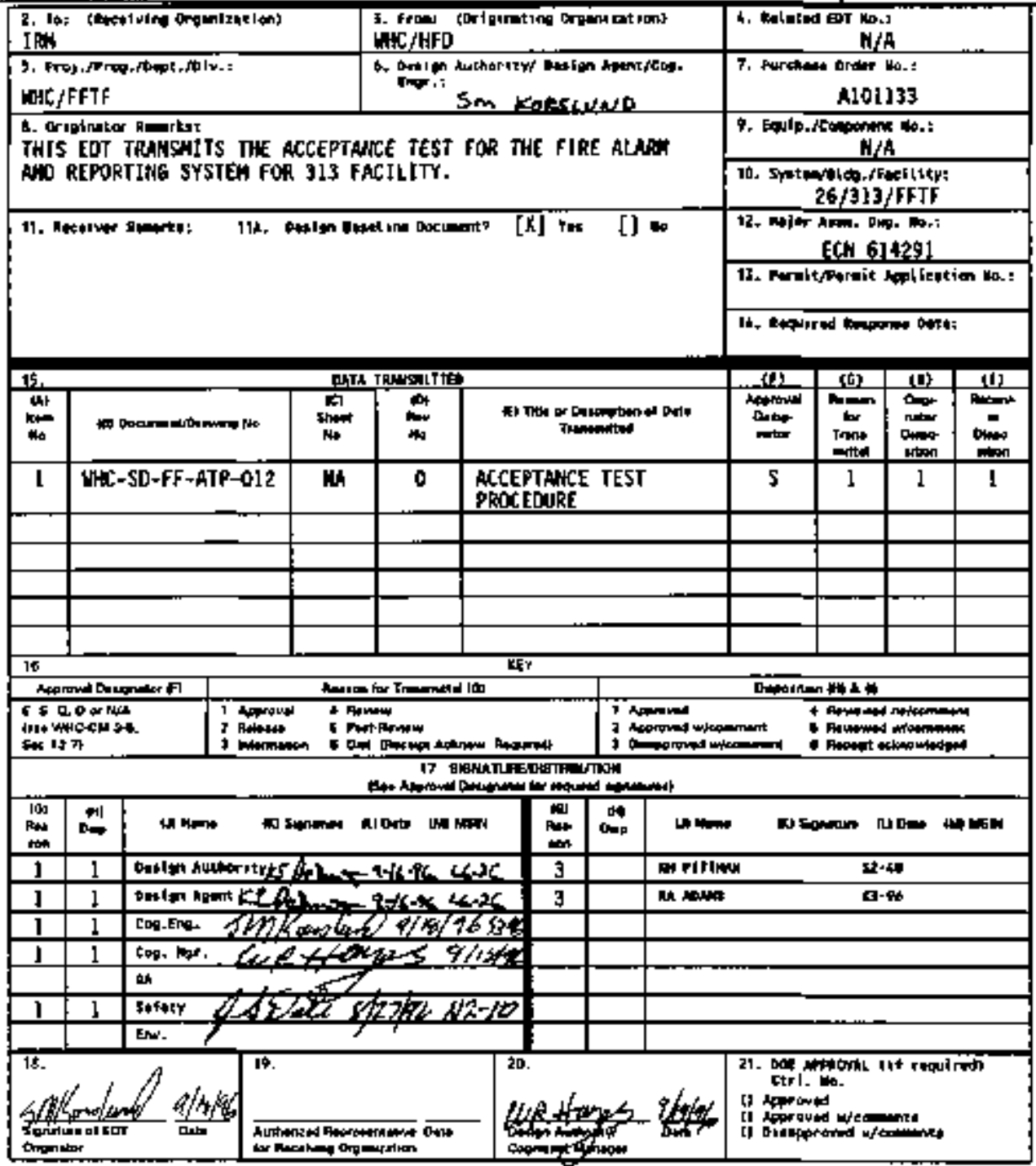

D.J400-172-2 [05,06] tonop? 


\section{Building FIRE ALARM SYSTEM}

sy Konstint

Lite, Richland, wh 99362

U.S. Department of Energy Contract DE-AC06-872010930 cross:

EDTIECN: -600431

org Code: 8R500

Bsk code: 900

UC: THO100000

Change tode: MFinow

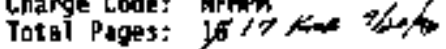

Key Hords: RFAR, FIRE MLARM

Abstract: Acceptance for test for AFAf Installation for factlity fire al arin and suppresston system.

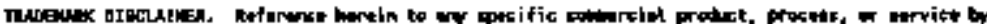

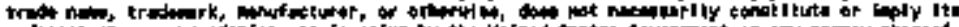

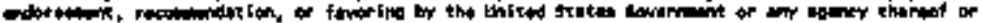

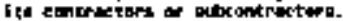

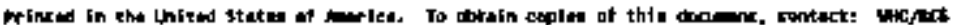

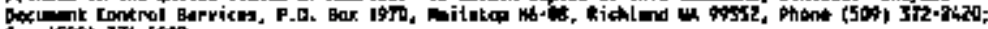

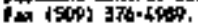
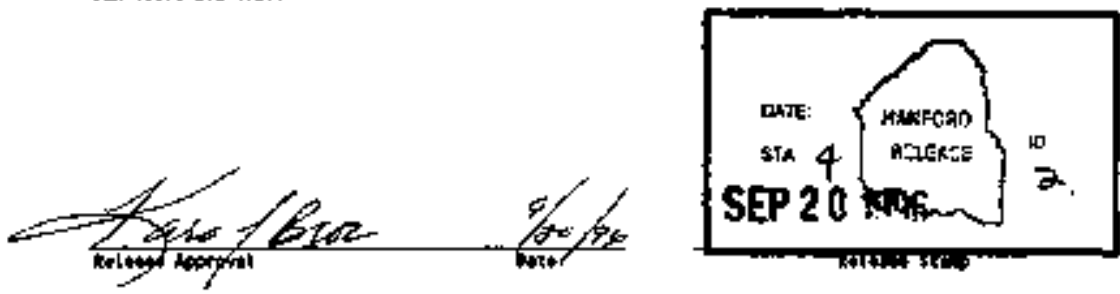

\section{Approved for Public Foleese}




\section{ACCEPTANCE TEST PAOCEDURE}

\section{FJRE DETECTIOA AHD SUPPRESSION FOR THE 313 BUILIUG}

August, 1996

TEST PROCEDURE APPFOYAL:

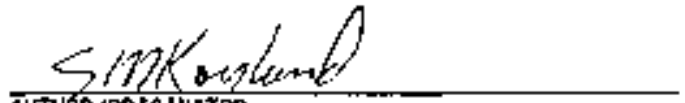

ALTTHOKR/DRIGINATOR
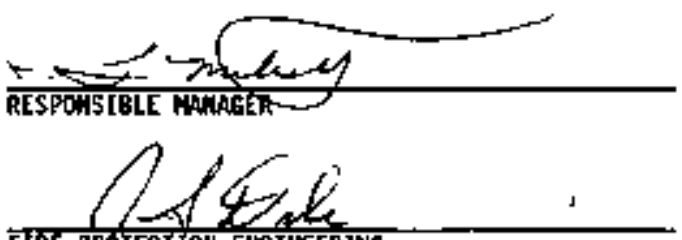

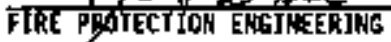

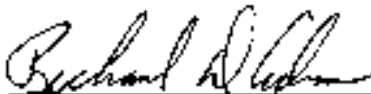

HTITOPOO FIRE DEPARTMEMT

\section{FIRE MARSHAL}
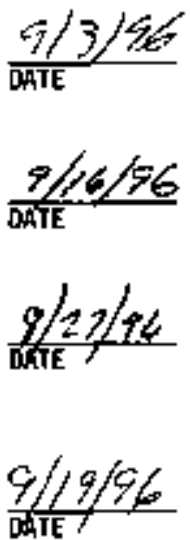
WHC-SD-FF-ATP-O12

REY. O

PAGE 2 of 16

\section{TEST EXECUTION SHEET}

\section{IESI EXECUTIOH}

$\overline{\text { Installer }}$ Date

Recardarforganization Dot

Tost Oirector/organization Date

\section{IfST U1THESS}

Witnoss/Organization

Date

Mitnessforganization

\section{IESI APPRONAL ND ACCEPTANCE}

Without Exception
With

Excegtion

Resolved
With

Exception Outstanding
Design Engineer (Author) Date

Fire Protection Engineer 'Date

[Tit]e or Departinent\} orte
Fre Systems Haintenance Date

Fanford Fire Departinent Date I

(Title ar Department) Date 
WHC-SD-FF-ATP-QIZ

REV. 0

PAGE 3 of 16

TABLE OF COWTEMTS

Section

Page

TITLE/PROCECOUAE APPBOHAL

EXECUTION AHD TEST APPROYRL

TABLE OF COMTEMS

PURPOSE

a

REFEREATES

4

CHANGE CONTROL

4

PREREQUI\$TITS

5

EQUJPAENT REQUJREO

6

FIRE ALAPW SYSTEN TEST

7

Appendix $" A^{n}$

14

EXCEPTIONS

15

LST PATE

16

WTE: At coepletion of test, enter pagas added during ptrformance of test to this Table of Contents. 
NHC.-SD-FF-ATP-O.12

REV. 0

PAGE 4 of 16

1 minose

This Acceptance Test Procedure (NTP) has bean prepared to damonstrate that tha Fire Protection systam alterations function as required by project criteria. 0nly the wodjicitions to the system are corered under this test scope.

2 NEFEREMES

2.1 Dranings

H-3-70054; H-3-70057, H-3-55896, sheats 1-3; all as andifled by ECh 614291 .

\subsection{Specifications}

$\operatorname{sic} 7 . \mathrm{B}$

2.3 Engineering Change Notices (ECN)

Seè 2.4

\section{4 chinge cohinot.}

Boquired changes to this ATP must be processed on ECHs in accordance with comany procedurzs. If a need far change Is discovered in the course of ruming the test. the test shall be stopped until the ECH is approved. However, this does not prevent the runiting of apother portion of the test undffected by the change.

\subsection{DESPOASIBIT ITIES}

Each company or organization partlcipating in the condect of this tast will designate personnal to assume the responstbilities of dutlas as dofined harain for their raspective roles. The nares of thest destgnators shall be provided to the racorder for Jisting on the recorder's copy of the test execut ion sheet prior to the perforeance of any part of this test.

\section{3.) EM IMER IH CHAHEE}

+Designate a tast director.

\subsection{TEST DIRECTOR}

tcoordinate gll acceptance testing.

\subsection{Hrticsses (Mrovidad by Particlaoting Organizations)}

-Witness the tests.

\subsection{RECORDER}

HDbserve tests and record test data.

\subsection{INSTALLER}




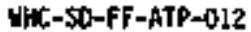

REV. 0

PAGE 5 OF 16

* Herify that the systam has succassfully undargone all necessary protesting and that the NTP way proceed and be coepleted in an expedit tous manher.

\subsection{OCCUPATIOHAL SAFETY HO WEATH}

Individuals shall carry out their assigned work in a safa mannar to protect thentelves and others frou hazards and to prevent danage to property and envirosiment.

- PREREqUISITES Na cquimant AEqujaED

1.1 Prarequisites

The following conditiahs shall exist at the start of the testing for that portion of the system being tested.

4.1.] Systeas havt been inspected for compliance with construction documents.

4.1.2 Referrnce dociments haye beap verifled for correct reyislon number and outstanding ECHs.

4.1.3 Appendix h, Oparability Test, for this ATP has been sat Isfactorily canoleted and signed by installer and witnass.

4.1.4 The RFAR panel has been vertfied operational and placod in service with al arms bypessad.

4.J.5 Power is ivallable.

4.1,6 Test instruments have valid calibration stamp attached.

4.I.7 The FACP standby battery has ben load cested at the 1 or $?$ hour discharge rate and verified to hold ct last $100 \mathrm{~s}$ af the namoplate rated capacity. The bettery has been recharged and has baen on charger for at least 46 hours in the past mak.

4.1.8 c02 systom discharge has been disabled or bypassed. 
4.2 Equipant and Instruments

Suppl ted by the Test operator unless otherwise noted.

4.2.1 Portable Volt-ohimeters (Non): Range a - so wolts oC and o - J nagohm.

Instrunent $M$ tit. Explation Date

4.2.2 Portable Nmeter: Range 0 - 10 amperes.

Instrument Ho. Explation Oate

\subsubsection{Swoke/Neat sourte.}

4.2.4 Electrical clip leads.

\subsection{Abbreviations}

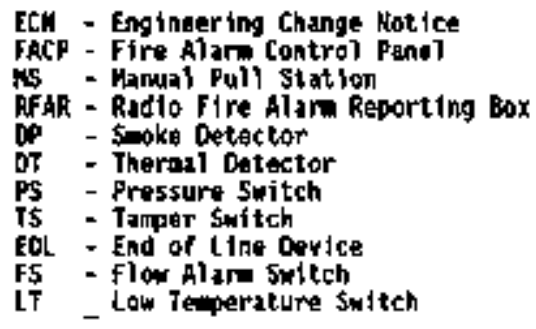


This ATP will test the Prrotronics 5ysta.. 3, CP-35 fire aldare control panel (FACP), and interfaces with the REAR, alardsupervisory initiating devites, and d) arm indicatiag spol lancas.

\section{5.] Preparation}

5.1.J Verify prerequisites of Subsection 4.1 have boen mot.

S.1.2 Request the Hanford Fire Oepartment dispateher bypass all signals fron the RFAR 3620 and acknowledge all supervisory and aldes receitued.

5.1.3 Antounce to personnel in butlding that a fire alare test is in progress; eyactation is not required.

5.1.4 Install Rfar door tamper switch overrighe device.

5.2 Pover Transfer and EN] tast: This tast will verify automatic transfer to battary upon ac poner interruption and restoration upon return to nowal. It will also verify the absence of Eas induced fallure to transtit RFAR signals on $A C$ power and on DC power backup supplies.

5.2.1 At power supply Dane1, open FACF supply bradker to interrupt ac Domer to facp. Panei EE, Circuit 7

5.2.2 Verify FACF ac power LED is aff and trouble audible is SOUNDJGG. silence trouble audible.

5.2 .3 At power supply panel, open RFAR supply. breaker to interrupt ac power to RFAR. Panel $X$, Circuit 1.

5.2.4 Verify "Local Panel Trouble" message followed after approxisately 90 second delay by "Com Irbil RFAR"

5.2 .5 Reset Facp and RFAR.

5.2.6 Cause an alarw on Zone 1 of the FACP, by flowing water, If epplicable, joupering the proper terminals or oporating an alarm oeviter.

5.2.7 Verify Zone J FACP and RFAR a larm LEDs com ON and systen alarm gonps soluin.

5.2.8 Verify "Zonte IN alaru" message recoived by dispatcher.

5.2.9 Close brakekers to restore ac powar to FACP and RFAR.

5.2.10 Verify FACP and RFAR ac poutr LEDs com ON. 
IHIC-50-FF-ATP-0I2

REV. 0

PAGE B of 16

5.2.11 silence alare bells. Do not reset FaCP.

5.2 .12 Cause an alarm on al1 subsequent zonos.

5.2.13 Verify alarm gongs \$0لur.

5.2.14 Verify alare receipt for each zone by the HFD dispatchar with all evactution signals sounding.

5.2.15 Raset FACP and RFAR.

Iable 5,2,14

\begin{tabular}{|l|l|}
\hline RFAR slgael rec'd & Slomature \\
\hline Zone 1 & \\
\hline Zone 2 & \\
\hline Zone 3 & \\
\hline Zone 4 & \\
\hline
\end{tabular}

5.3 Circuit Superviston; Th1s test w1ll werify RFAR Zone switch position and both goang and input zohe wiring are supervilsed per NFPA 72 .

5.3.1 RFAR 5oitch and etreute superwision:

5.3.1.1 Request Radio Maintenance switch all ofar zones to OfF.

5.3.1.2 Verify all RfAR zone trouble Lells come ON.

5.3.J.3 Verify "Coe Trouble (RfAR)" mess bge recoluad by dispatcher.

5.3.1.4 Request Radto Natntenance switch all afak zones Den and respt.

5.3.J.5 Verify all RFAR alarm and trouble LEDs are off.

5.3.2 FACP zont superyision: Record the following steps for the item shown on Data Sheet 5,3,2.

5.3.2.1 Disconnect the end of line (E.O.L) dortes for the indicated zane. This ady be perforded at any point in tbe circuit if installation wiring wethods wre vorified during the operability test.

5.3.2.2 Yerify FaCP gystem and zons/audible cirauit trouble LEOS are on.

5.3.2.3 Yerify "Local Panal Trouble" wessage for RFAR received by dispatcher. 
WWES-SD-FF-ATP-OIZ

REV. 0

PACE 9 of 16

5.3.2.4 Raconiect the E.O.L devite. Keset FACP and RFAR.

5.3.2.5 Verify FACP system, zone/audible circuit, and RFAR trouble LEDs are OFF.

\begin{tabular}{|c|c|c|c|c|c|c|c|c|}
\hline \multirow{2}{*}{ STE } & \multirow{2}{*}{ PERFONY/NERIFY } & \multicolumn{7}{|c|}{ IMU/AURIBLE ZOWE } \\
\hline & & $\mathbf{7 1}$ & $\boldsymbol{Z Z}$ & $\mathbf{2 3}$ & $\boldsymbol{z u}$ & s! & $\mathbf{6 1}$ & 62 \\
\hline 5.3 .2 .1 & Disconnect E.0.L. dertice & & & & & & & \\
\hline 5.3 .2 .2 & Trouble LeEs are ow & & & & & & & \\
\hline 5.3 .2 .3 & Irouble nessage received & & & & & & & \\
\hline 5.3 .2 .4 & Reconnect E,O.L, derice & & & & & & & \\
\hline 5.3 .2 .5 & Trouble LEDs are off & & & & & & & \\
\hline
\end{tabular}

5.3.2.6 Attach an electrical clip lead fros any superylsad intiating circuit or notification appliance circuit and verify ground faut trouble indication occurs. Reave clip lead.

\$.4 Alarm and Supervisory Test: This test w111 vetrify the inftiation device capability of all alin and suporvisory inpet cireuits.

5.4.J Recard the following steps for each device shom on Data Shept 5+4.].

5.4.1.] hetivate the device.

5.4.J.2 Verify FACP Zone alandtrouble LED is OH.

5+1+3 Verify FACP system alare/trouble LED is ON,

5.4.J.4 Verify RfaR Zore al are/local troublo LED comes on and appropristo cessage roteived by dispatcher.

5.4.1.5 Reset the inftiating derice

5.4.1.6 Reset FACP and kFAk and verify FitP/Rfar cleat of alam and trouble. 


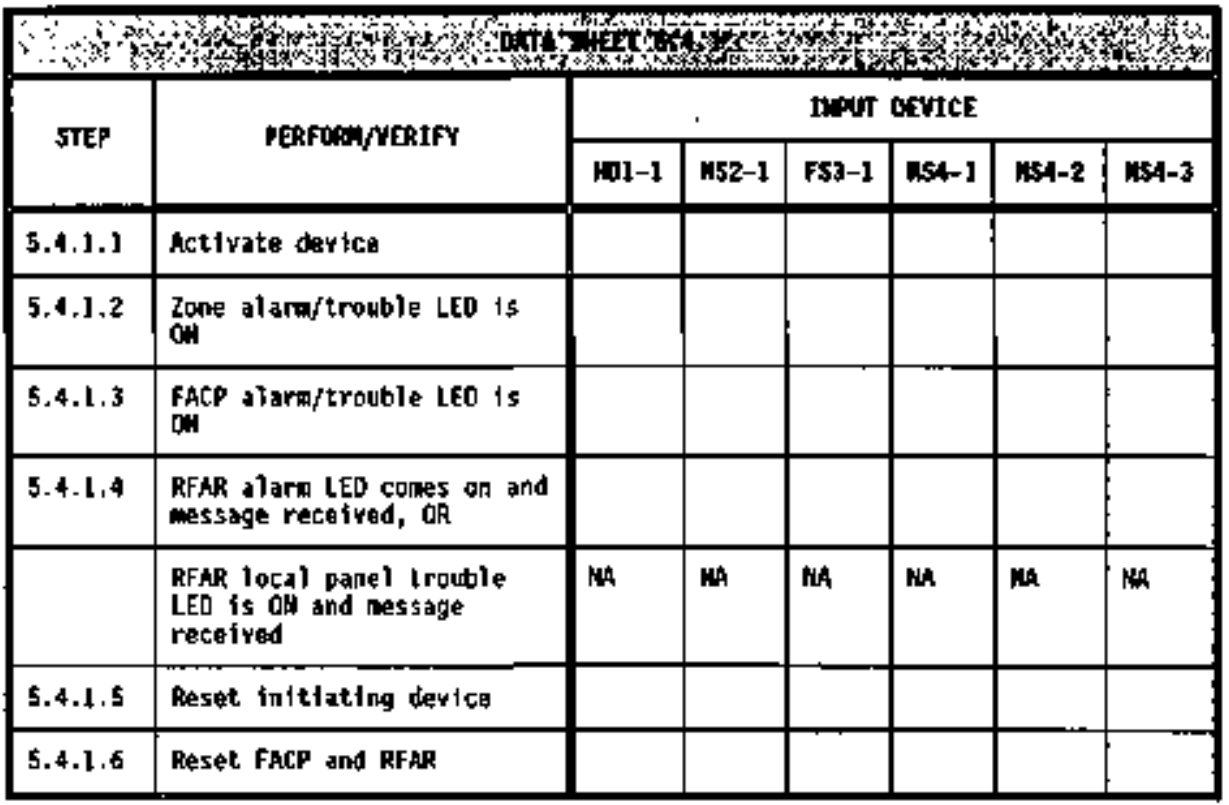


WHC-SD-FF-ATF-O12

REV. 0

PAGE II of 16

\begin{tabular}{|c|c|c|c|c|c|c|c|c|}
\hline \multirow{2}{*}{ STEP } & \multirow{2}{*}{ MERFORM/NERIFY } & \multicolumn{7}{|c|}{ Input pevite } \\
\hline & & $\begin{array}{c}1591 \\
-4\end{array}$ & $\begin{array}{c}n 54 \\
-5\end{array}$ & $\underset{-4}{\min }$ & $\begin{array}{l}\cos 4 \\
-7\end{array}$ & $\begin{array}{l}\text { MS4 } \\
-8\end{array}$ & $\begin{array}{l}\text { RS4 } \\
-9\end{array}$ & Lo5- \\
\hline $5,4,1,1$ & Activate device & & & & & & & \\
\hline $5.4,1.2$ & Zong alaraftrouble LED is on & & & & & & & \\
\hline $5.4,1.3$ & FACF aldre/trouble LED Is on & & & & & & & \\
\hline 5.4.1.4 & $\begin{array}{l}\text { RFAR alara LED coues an and } \\
\text { message received, DR }\end{array}$ & & & & & & & HA \\
\hline & $\begin{array}{l}\text { RFAR local panal trouble LED } \\
\text { is ow and message recetrod }\end{array}$ & NA & MA & $\mathrm{MA}$ & MA & & & \\
\hline $5.4,1.5$ & Resot initiating deyice & & & & & & & \\
\hline 5.4 .1 .6 & Resat FACF and RFAR & & & & & & & \\
\hline
\end{tabular}

5.5 Battery Orm Dom/alare Audfbility Test: Thls tesi will verify battery capacity and system recharge capability as wll as Yerify audibility of the fire alarn appliances. This test will also verify the absence of EN]induted fatlure to transmit RfAR signals.

5.5.1 Disconnect ane battery lead' and terify FACP systam trauble LED is on.

5.5.2 Connect anester in battery/banel circujit, reconnect battery to pantl, and vertfy facp systea tribute liED is DFF.

5+5.2.l Record battery voltage.

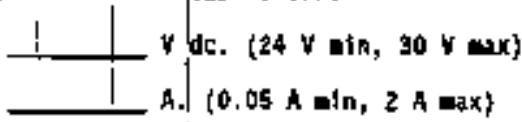

5.5.2.2 Record batterry current.

5.5.3 Deen The face supply brealer to interrupt ac powar. Retord date/tioe

5.S.3.1 Merify ac power trouble indlacatidn. 
WHC-SD-FF-ATP-OLL REV. 0

PAGE 12 of 16

5.5.3.2 Record battery voltage. $v$ dc. $(21 \vee a i n, 30 \vee \max \}$

5.5.3.3 Record battery discharge current. A. 7 A max.

A. [0.05 A with,

5.5.4 Cause an alan on the FacP, by operating a device or jumpering the apprapriate terminals.

5.5.4.1 Yerify fACP Zont and RFAk Zont alanm LEOs como OH.

5.5.4.2 Verify three round: of firs alanm mossugo "Zone _N" received by the dispatcher.

5.5.4.3 Ferify building alans 50lwid for 1 minimum of 5 einutes, and perforn the following during this period.

5.5.5 hudibllity: This lest will verify that gong addibility

is adequate for the areas covered and required visual signals operate corractly. Record the following steps for the alaris shown on Cats Sheet $5.5,6$.

5.5.5.1 Verlfy audible signals are clearly heard and distinguishable thoughout the facility.

\begin{tabular}{|c|c|c|c|c|c|c|}
\hline \multirow{2}{*}{ STEP } & \multirow{2}{*}{ PEIFONM/NER LFY } & \multicolumn{5}{|c|}{ Gonis/sTh0oE } \\
\hline & & (4)-1 & 61-í & 61-3 & $\mathrm{Hz}-1$ & H2-1 \\
\hline 5.5 .5 .1 & gong audible & & & & & \\
\hline
\end{tabular}

S.5.5.3 Retord battery voltage. Record discharqe current. $4 \mathrm{dc}$. [2l Y mín, 30 V max] . (0.05 A, 由łn, $4.7 \mathrm{~A} \omega x)$

\$.\$.\$.t sllence alarm gongs.

\subsubsection{Reset FAtP/RFAR.}

5.5.6 Recharge Function:

5.5.6.l clo5e and secure breaker.

5.5.6.2 Record battery charge current. min, $2 A$ max $]$

A. $10.05 \mathrm{~A}$ 
WC-5D-FF-ATP-012

REV. 0

PAGE 13 of 16

5.5.6.3 Recowt ameter fron battery circuit, reconnect battery to panel.

5.5.6.4 Rewove RFAR door tamper sutth overrida davies.

\$.\$.6.5 Rej̧et FACP and request Radia Maintenance reset and secure AFAR box.

5.7 Secure Frou Test:

5.1.1 Yerify all detection devices hava been reset and are in mophal condition.

5.7.2 Verify FACP is in Nowal condition and secured.

5.7.3 Request Manford Fire Departeent to restorg all zones on the RFAR.

5.7.4 Verify RFAR is in MOPanl condition and secured.

5.7.5 Depress bittion on front of hfak 80X 3isial.

5.7.6 Yorify threg rounds for the RFAR front button recolived by the dispatcher.

5.7.7 hdise the dispatcher that testing 15 complets.

5.7.8 Announce to building persobinel that testing is colpolete.

ED OF TEST 
WHC-SO-FF-ATP-0I2

REV. 0

PAEE It of 16

APPENDIX A

A. PURPOSE: This sppeadix is proy ided as a checklist of activitias and verifications to bo porfored by the firt alde systan installer to ensure proper installation and operation. Respons bilifty for cololetion of the following items are the responsibility of the installer.

B. JKSTALLER: Prior to terminating conductors that have been laid or pulled autside of the fire alarm pane?. perfork and document the following:

1. Yerify that all conductors other than thase intentionally and permanently grounded have been tested for isolition from groumd using an insulation testing device.

2. Verify that all conductars have been tasted for conductorto-conductor isolation using an insulat ion testing dewice.

3. Verify that extarnal circuit loop rasistance agesuraments are within the folloring limit.5 or as andufacturer specifies:

1. Naxioum 36 ohes for initiatiag devica input circuits.

b. Haxinum 7.5 ohms for al are/befl output elreults.

c. IMSTALLER and IMSPECTOR: After comigting the terpinations of the systom and conductors in atcardance with the installation drawings, perfore and verify the following:

1. Verify that the system is installed and wired in actordance with the installation drawings.

2. Inspect each Initiating davies and alarm output device and verify that the conductors are properly wirad.

3. Verify that each required end-of-line deyice is in place.

4. With battery installod and nomal power supplied, verify that the FACP is in a mien superytsory condition as def ined by the manufacturer's manual.

5. By 1ifting leads or end-of-line deylces, werify that aach superytsed zonte produces proper trouble indication.

6. Vorify that each alare/superylsory initiating device produces proper alarm conditions when sctirated.

7. Verffy that alarw bellsfehines/strobes operate properly .

8. Verify that auxiliary functions (eg., HrAC shutchon) operato correctly per the design. 
HHC-SA-FF-ATP-OLIS REV. 0

PASE 15 OF 18

\section{EXCEPTION SHEET}

DATE:

Objecting Party

Dit*

organization

Date

EXCEPTION:

BLAKIEO ACINOA:

ACTUOA TAKE:

OATE:

PEIEST EXECUTIOW AHF ACCEPTANCE:

Rotest approved Excaption

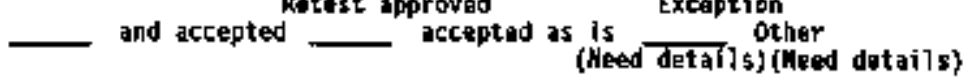

Detafls: 
IHE-SD-FF-RTP-OI2

ReV. 0 PAGE 16 of 16

\section{EXCEPTION SHEET (Continuation Page)}

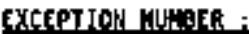

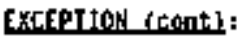

PAHLED ACTIOAL conth:

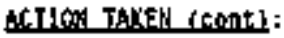

DEIALLS (cont):

DATE:

Pagt _ of 